\title{
Lake Watershed Dynamics and Bathymetry Modeling of Rara and Begnas Lakes in Nepal
}

\author{
Sudeep Thakuri ${ }^{1,2, *(D)}$, Furbe Lama ${ }^{1}$, Rabin Malla ${ }^{2}$, Nitesh Khadka ${ }^{3,4}{ }^{\mathbb{D}}$, Narayan Prasad Ghimire ${ }^{5}$ \\ and Franco Salerno 6 (D)
}

1 Central Department of Environmental Science, Tribhuvan University, Kirtipur 44613, Nepal; dccs_dailekh@asha.gov.np

2 Center of Research for Environment, Energy and Water, Kathmandu 44616, Nepal; rabin@creew.org.np

3 Institute of Mountain Hazards and Environment, Chinese Academy of Sciences, Chengdu 610041, China; nkhadka@imde.ac.cn

4 University of Chinese Academy of Sciences, Beijing 100049, China

5 Central Department of Botany, Tribhuvan University, Kirtipur 44613, Nepal; np.ghimire@cdbtu.edu.np

6 Water Research Institute (IRSA-CNR), 20861 Brugherio, Italy; salerno@irsa.cnr.it

* Correspondence: sthakuri@cdes.edu.np; Tel.: +977-9851101011

Citation: Thakuri, S.; Lama, F.; Malla

R.; Khadka, N.; Ghimire, N.P.;

Salerno, F. Lake Watershed Dynamics and Bathymetry Modeling of Rara and Begnas Lakes in Nepal. Earth 2021, 2, 272-286. https://doi.org/ $10.3390 /$ earth2020016

Academic Editor: Hossein Bonakdari

Received: 16 April 2021

Accepted: 3 June 2021

Published: 5 June 2021

Publisher's Note: MDPI stays neutral with regard to jurisdictional claims in published maps and institutional affiliations.

Copyright: (c) 2021 by the authors. Licensee MDPI, Basel, Switzerland. This article is an open access article distributed under the terms and conditions of the Creative Commons Attribution (CC BY) license (https:/ / creativecommons.org/licenses/by/ $4.0 /)$.

\begin{abstract}
Lake evolution and its changes over time are an evident and easily measurable signal of human activities and climate change impacts in mountain regions. This study presents bathymetric modeling of permanent lakes (Begnas and Rara Lakes) located in two different geographic settings of Nepal. Moreover, temporal changes in land cover and soil erosion of the lake watersheds, as well as climatic trends around these lakes, are assessed. This study supports establishing reference sites for exploring scientific evidence on the impacts of anthropogenic and climate change on lake hydrological systems. Second-order polynomial models best represent the relationship between lake depth and volume. Rara Lake had a maximum depth of $169 \mathrm{~m}$ with an area of $10.52 \mathrm{~km}^{2}$ and a volume of 1013.305 million cubic meters $\left(\mathrm{Mm}^{3}\right)$, whereas Begnas Lake had a maximum depth of $12.5 \mathrm{~m}$ with an area of $2.98 \pm 0.10 \mathrm{~km}^{2}$ and a water volume of $13.539 \mathrm{Mm}^{3}$ in the year 2019. Both lake regions are experiencing changes in temperature and rainfall. The area and volume of Rara Lake and its watershed have been relatively stable even with minimal land-cover change during the recent decades. Begnas Lake and its watershed have experienced significant changes in the last few decades. This study concludes that human activities in the Begnas Lake watersheds are the primary source of lake area variation rather than climate change.
\end{abstract}

Keywords: bathymetry; depth-volume relationship; lake; water level; water volume

\section{Introduction}

The distribution and abundance of lakes play a significant role in assessing biogeochemical cycles, hydrological conditions, and ongoing climate change [1-3]. Changes in high-altitude (>3000 $\mathrm{m}$ above sea level, a.s.1) lakes, as well as their evolution and dynamics, are well studied as they are an evident and easily measurable signal of climate change [4,5]. Bathymetric measurements of some typical glacial lakes in the Nepalese Himalaya are repeatedly taken to prepare bathymetric maps to calculate the depth and storage volume of lakes as they are susceptible to glacial lake outburst floods (GLOFs) [6-8]. In addition to glacial lakes at high altitudes, there are several vital lakes at low altitudes $(<3000 \mathrm{~m}$ a.s.l.) across Nepal (e.g., Begnas and Rara lakes), which are environmental and social assets to Nepal [9-11]. Studies on such lakes are essential as they provide ecosystem services on the basis of their ecosystem function [12]. Additionally, they are a source of freshwater, irrigation, and recreation; however, there are limited studies on such types of lakes in Nepal $[10,13]$. Previous studies studied the morphology and bathymetry of these lakes [14-16], but updated data do not exist. 
The rapidly depleting freshwater resources and frequent floods during the past decade pose a severe threat toward sustainable agriculture in the rapidly populating and climatically changing South Asian region [17-19]. Furthermore, the lake area and vegetation are responding to the changing climate $[1,20,21]$. Notwithstanding the present apparent symptoms of climate change causing the non-availability of water at the right time, existing traditional practices, skills, and drought/flood risk mitigation practices on watersheds are not sufficient to cope with the substantial emerging issues and risks. Consequently, a significant impact of climate change on people's livelihood in remote watersheds has been reported, especially in South Asia [18,22].

Ten wetlands, including several lakes, are designated as Ramsar sites in Nepal. Most of these Ramsar sites are touristic places, but they are crucial for biodiversity, the natural water cycle, climatic regulation, and ecological balance [23,24]. The cluster of lakes in Pokhara valley, including Begnas Lake, is collectively listed as one Ramsar site. Acharya and others [25] studied the surface area changes of three lakes in Pokhara Valley during 1988-2013. They found that Phewa and Begnas Lakes were shrinking, whereas Rupa Lake had increased surface water area. Phewa Lake was reported to be shrunken due to increased sediment flux from the surrounding agricultural lands and watershed degradation.

Additionally, it has been analyzed that lakes will significantly lose their storage capacity in the upcoming centuries, thereby affecting tourism [26]. The oligotrophic Rara Lake, one of the Ramsar sites of Nepal, is the largest lake in Nepal. Bathymetric measurements during 1982-1984 revealed the mean and maximum depth of the lake to be 100 and $167 \mathrm{~m}$, with a water volume of $0.98 \mathrm{~km}^{3}$ [16]. Similarly, a bathymetric survey in 2009 revealed the maximum depth to be $169 \mathrm{~m}$ in the western part of Rara Lake [14]. Furthermore, this lake was supposedly formed by tectonic activity (along a series of dextral active faults) and detritus embankment. These lakes are under the direct impacts of ongoing climate change and anthropogenic stress [3].

In light of the interlinked relationship among human activities, climate change, and temporal changes of lakes, this study aimed to comprehensively evaluate two lakes located in different climatic conditions. This study explored the lake variations and impacts of anthropogenic and climate change on the depth, area, and water volume of Begnas and Rara Lakes, located in two different geographic settings of Nepal, to establish reference sites for exploring the scientific evidence of climate change impacts on the hydrological system. The lake morphology was evaluated using bathymetric modeling, and a model was established for representing the water volume and depth of the lakes. Recent and up-todate bathymetric data of lakes are useful not only for identifying the morphometry of lakes, but also for revealing the effects of climate change, determining sediment transport into the lake, and hydrodynamic modeling. This study used a consistent method for measuring the depth of the lakes, which will be significant for their monitoring, and the results further provide a basis for future lake preservation and maintaining the wetland ecosystem.

\section{Study Area}

This study was focused on two oligotrophic freshwater lakes: (1) Rara Lake and (2) Begnas Lake (or Tal in the Nepali language for lake), located in the Nepal Himalayas (Figure 1). These lakes were selected due to their locations in two different geographic settings with distinct climatic characteristics.

Rara lake is an alpine lake situated in the Rara National Park, in far western Nepal, covering a surface area of $10.61 \mathrm{~km}^{2}$ at an elevation of $2990 \mathrm{~m}$ a.s.l. The lake contributes water to the Karnali River, one of the three major river basins (namely, Karnali, Gandaki, and Koshi) in Nepal. This lake was declared a Ramsar site in 2007. The maximum depth of Rara Lake measured in 2009 was 169 m [14], suggesting it as the deepest Lake in the Nepal Himalayas. Nevertheless, the official maximum depth of the lake is considered to be $167 \mathrm{~m}$. A thermocline in this lake was observed below 14 to $50 \mathrm{~m}$ and was recorded as 7.5 to $7.6^{\circ} \mathrm{C}$ [27]. The lake is classified as oligotrophic in limnological terms, whereby it is 
very slightly polluted according to studies carried out on estimations of chlorophyll $a$, total nitrogen, and dissolved oxygen [16].
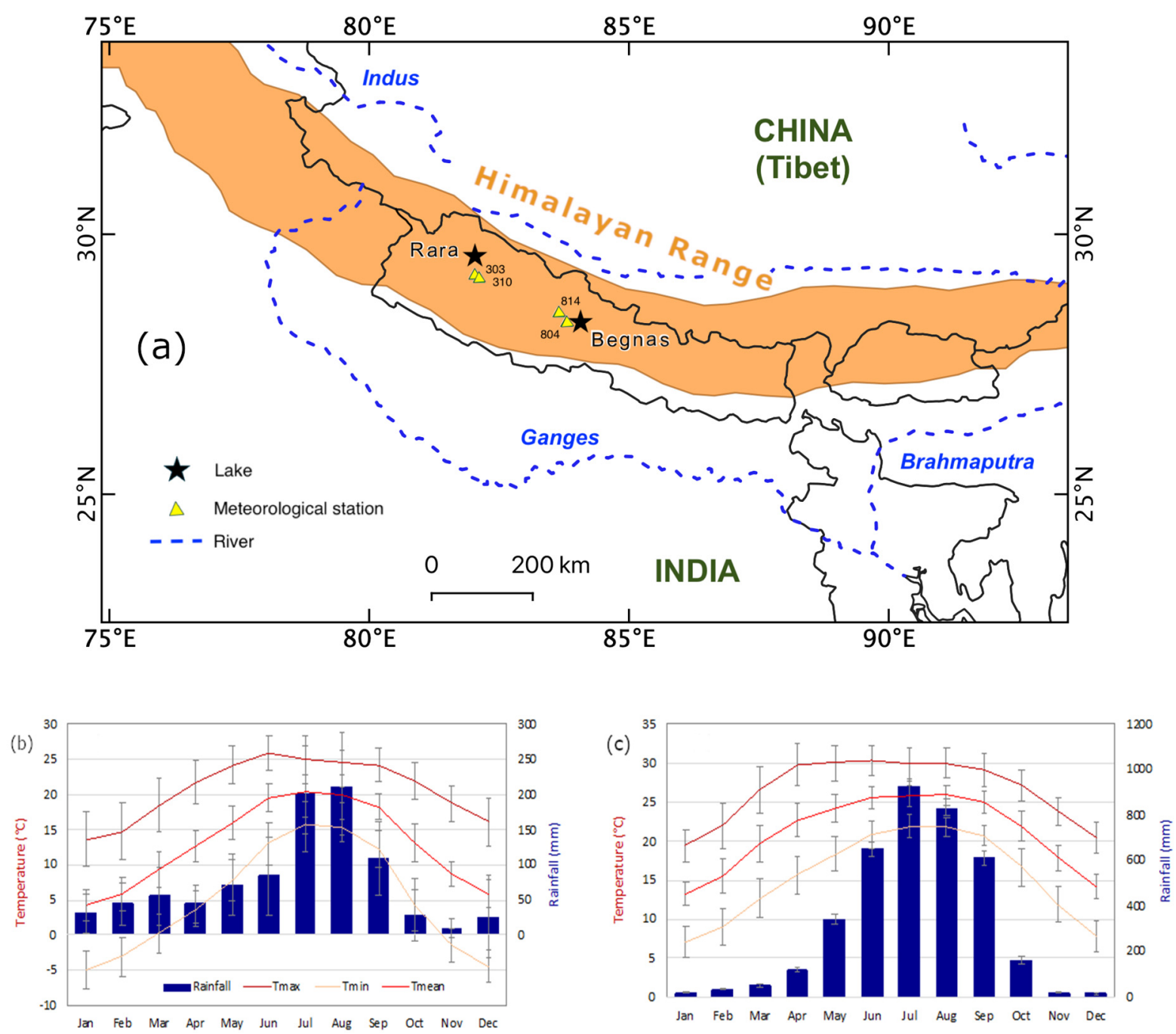

Figure 1. Location of the study areas: (a) Rara and Begnas Lakes in Nepal. Mean monthly cumulative rainfall and minT, MaxT, and MeanT for (b) Rara and (c) Begnas Lakes.

Begnas Lake is a subtropical lake, situated in central Nepal at an elevation of $650 \mathrm{~m}$ a.s.l. and covering a surface area of $3.28 \mathrm{~km}^{2}$, with a maximum depth of $7.5 \mathrm{~m}$ and an average depth of $4.6 \mathrm{~m}$ [28]. This lake, along with eight other lakes around its periphery (in Pokhara and Lekhnath) was designed as the 10th Ramsar site of Nepal [29]. Begnas is the third-largest freshwater natural lake after Rara and Phewa Lakes in Pokhara valley. The lake has an unstable temperature stratification. At the surface, the water temperature varies from 15.1 to $30.3^{\circ} \mathrm{C}$ throughout the year [30]. Anoxia occurs below $3.2 \mathrm{~m}$ depth [31]. At $6 \mathrm{~m}$ depth, dissolved oxygen is deficient (less than $1 \mathrm{mg} / \mathrm{L}$ ) from March to October. The surface water is mostly somewhat oversaturated with dissolved oxygen. The lake was previously investigated in two seasons to examine the influence of the monsoon on its limnological conditions [32,33]. The calcium concentration in Begnas Lake accounted for $43 \%$ of cation and anions, predominantly bicarbonate. A complete limnological investigation was carried out in Nepal in 1989, during which 50 lakes were surveyed, including Begnas Lake from Pokhara Valley [34]. Furthermore, a few other studies are available on the limnology of the lake $[28,35]$. 


\section{Materials and Methods}

\subsection{Data Source}

\subsubsection{Bathymetric Survey}

The study of lake bathymetry involved the hydroacoustic method [36]. The bathymetric survey was conducted using a depth sounder (HDR 650 Humminbird ${ }^{\circledR}$ ) and the Garmin GPS 64st. The depth sounder had the capability of measuring depth up to $180 \mathrm{~m}$. Before applying the depth sounder, it was calibrated, and offsets were addressed. The Garmin GPS 64st had a position accuracy of $3 \mathrm{~m}$. More than 415 depth points of Begnas Lake and 682 depth points of Rara Lake were recorded. The morphological characteristics of the lakeshore (including mountain slope, inlets, outlets, and land use) were collected.

\subsubsection{Climate Data}

Temperature and precipitation data from the ground stations were used to analyze the climatic trends over the locations of two lakes. The meteorology data in Nepal are collected and managed by the Department of Hydrology and Meteorology (DHM), Government of Nepal. The DHM was the primary source of the ground station data, while an online database was used for the projected data. The information on the meteorological stations used is presented in Table 1.

Table 1. Ground meteorological stations used from the Department of Hydrology and Meteorology, Nepal.

\begin{tabular}{|c|c|c|c|c|c|c|c|c|}
\hline \multirow{2}{*}{$\begin{array}{l}\text { Station } \\
\text { Index }\end{array}$} & \multirow{2}{*}{ Location } & \multirow{2}{*}{ Station Type } & \multirow{2}{*}{$\begin{array}{l}\text { Lat } \\
{ }^{\circ} \mathbf{N}\end{array}$} & \multirow{2}{*}{$\begin{array}{c}\text { Long } \\
{ }^{\circ} \mathrm{E}\end{array}$} & \multirow{2}{*}{$\begin{array}{c}\text { Elevation } \\
\text { m a.s.1. }\end{array}$} & \multirow{2}{*}{$\begin{array}{c}\text { Data } \\
\text { Availability }\end{array}$} & \multicolumn{2}{|c|}{$\%$ Missing Values } \\
\hline & & & & & & & $\begin{array}{c}\text { Air } \\
\text { Temperature }\end{array}$ & Rainfall \\
\hline 804 & $\begin{array}{c}\text { Pokhara } \\
\text { Airport }\end{array}$ & $\begin{array}{c}\text { Aeronautical, } \\
\text { manned and } \\
\text { automatic }\end{array}$ & 28.20 & 83.97 & 827 & 1968-2013 & 1 & 4 \\
\hline 814 & Lumle & Agrometeorology & 28.18 & 83.48 & 1740 & 1969-2013 & 1 & 2 \\
\hline 303 & Jumla & Synoptic, manned & 29.27 & 82.18 & 2366 & 1976-2015 & 7 & 3 \\
\hline 310 & Dipal Gaun & $\begin{array}{l}\text { Climatology, } \\
\text { manned and } \\
\text { automatic }\end{array}$ & 29.16 & 82.13 & 2310 & 1985-2015 & 3 & 8 \\
\hline
\end{tabular}

\subsubsection{Spatial Data}

Multi-sensor and multi-source spatial data were used in this study (Table 2). The available (i) satellite data (Landsat Multispectral Scanner System (MSS), Thematic Mapper (TM), Enhanced Thematic Mapper (ETM+), and recent Sentinel 2) and (ii) the Terra Advanced Spaceborne Thermal Emission and Reflection Radiometer (ASTER) Global Digital Elevation Model (GDEM) were used for obtaining the basin characteristics, land-cover change, and lake surface area changes. The online database of the United States Geological Survey (USGS Earth Explorer) was used to obtain satellite data (Landsat, Sentinel 2A/2B, and ASTER GDEM). The evolution of Rara and Begnas Lakes was studied using multi-temporal imagery taken during the post-monsoon seasons from 1976 to 2019. 
Table 2. Satellite data used in the study.

\begin{tabular}{ccccc}
\hline Satellite/Sensor & Acquired Date & $\begin{array}{c}\text { Spatial } \\
\text { Resolution }(\mathbf{m})\end{array}$ & $\begin{array}{c}\text { Number of } \\
\text { Bands }\end{array}$ & Scene ID \\
\hline Landsat MSS & 28 October 1976 & 60 & 4 & LM02_L1TP_152041_19761028_20180424_01_T2 \\
& 30 October 1976 & 60 & 4 & LM02_L1TP_154040_19761030_20180424_01_T2 \\
\hline Landsat TM & 7 November 1989 & 30 & 7 & LT05_L1TP_142041_19891107_20170201_01_T1 \\
& 3 December 1990 & 30 & 7 & LT05_L1TP_143040_19901203_20170127_01_T1 \\
& 30 October 2010 & 30 & 7 & LT05_L1TP_144040_20101030_20161012_01_T1 \\
& 1 November 2010 & 30 & 7 & LT05_L1TP_142041_20101101_20161012_01_T1 \\
\hline Landsat ETM+ & 15 December 2000 & $30 / 15^{*}$ & 8 & LE07_L1TP_142041_20001215_20170208_01_T1 \\
& 20 November 2000 & $30 / 15^{*}$ & 8 & LE07_L1TP_143040_20001120_20170209_01_T1 \\
\hline Sentinel 2B & 7 December 2019 & 10 & 13 & L1_T44RQS_A023282_20191207T050809 \\
& 25 November 2019 & 10 & 13 & L1C_T44RPT_A014202_20191125T051334 \\
\hline
\end{tabular}

\subsubsection{Land-Cover Classification and Soil Erosion Estimation}

The land-cover data of Rara and Begnas Lake watersheds were obtained from the classification of satellite imagery of 1990 and 2017 using a supervised classification algorithm that segmented the spectral domain into the classes of interest [12].

Soil erosion was estimated for the two lake watersheds using the empirical Revised Universal Soil Loss Equation (RUSLE) model and the same dataset as in Koirala et al. [37]. The model uses the soil types, ASTER GDEM, land cover, and rainfall data, and it is applicable for rill and interrill soil erosion due to the impact of raindrops.

\subsection{Data Analysis}

\subsubsection{Bathymetric Analysis}

The depth data collected for each lake water column were used to model the depthvolume relationships. First, we generated the bathymetric maps and lake terrain elevation models. Furthermore, the area and volume of the lakes were computed. Empirical statistical models were developed for estimating the water volumes (depth-volume relationship). GIS analysis was conducted for the lake surface area variation analysis $[11,38,39]$.

The Surfer software was used for developing the bathymetric model with kriging spatial interpolation - a geostatistical interpolation technique-by using a semi-variogram to quantify the spatial patterns of regionalized variable and derive important input parameters $[40,41]$. The spatial relationship can be expressed as

$$
\gamma(h)=\frac{1}{2 N(h)} \sum_{i=1}^{N(h)}\left[z\left(x_{i}\right)-z\left(x_{i}+h\right)\right]^{2},
$$

where $z\left(x_{i}\right)$ is a measured sample at a point $x_{i}, z\left(x_{i}+h\right)$ is a measured sample at point $\left(x_{i}+h\right)$, and $N(h)$ is the pair number separated by lag interval or distance $h$.

The semi-variogram was fitted with spherical, exponential, and Gaussian models. These models provided information about the spatial structure of the fitted models and the input parameters for kriging such as the nugget effect (which occurs at distances smaller than the sampling interval), partial sill or structural variance, and sill variance (i.e., the total variance indicating the distance beyond which samples are considered to be spatially independent, causing the semi-variogram not to be increasing with increasing distance). The correlation length or range (a) was derived from the fitted semi-variograms. The best-fitted model for bathymetry was finally selected.

Validation of the models was performed through the extraction of random points in the interpolated layer and comparison with the independent depth data. 


\subsubsection{Climatic Trends}

Following [42,43], the maximum proportion of missing observations allowed for the analysis was $10 \%$. The missing values were not filled, but they were retained in the series to avoid bias in assessing the trend. The maximum and minimum temperature data series were manually inspected for all stations and all years as a preliminary quality control. Any suspicious values, for example, a maximum temperature value lower than the corresponding minimum temperature value, were removed. The most commonly used approach for trend detection is a parametric test by formulating a linear model between the data and time [44].

\section{Results and Discussions}

\subsection{Lake Bathymetry}

\subsubsection{Rara Lake}

Figure 2 shows the bathymetric model of Rara Lake. The maximum depth recorded in Rara Lake was $169 \mathrm{~m}$ at the western end, with a mean depth of $90 \mathrm{~m}$. The estimated water volume of the lake was 1013.305 million cubic meters $\left(\mathrm{Mm}^{3}\right)$. The basin area of the lake was $10.52 \pm 0.10 \mathrm{~km}^{2}$. The estimated volume of Rara Lake $\left(1013.305 \mathrm{Mm}^{3}\right.$ or $1.01 \mathrm{~km}^{3}$ in this study is comparable to the $0.98 \mathrm{~km}^{3}$ reported in 1986 [16]. The primary sources of water for the lake are seasonal rainfall, groundwater, and seasonal snowmelt. The interpolated map shows that the depth is highest in the northwest part of the lake, with an abrupt shift in depth toward the lakeshore. We established a second-order polynomial model to explain the relationship between lake depth and volume (Figure 3).

(a)

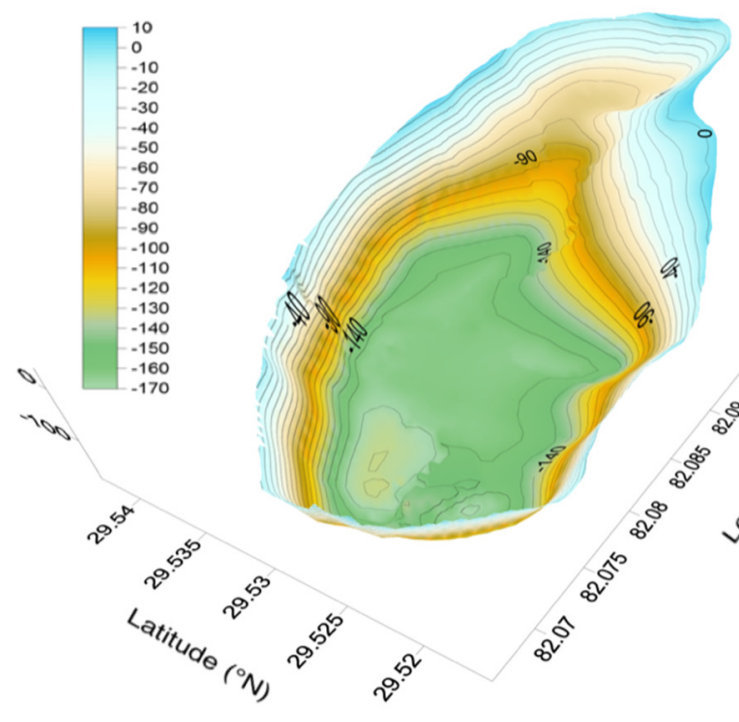

(b)

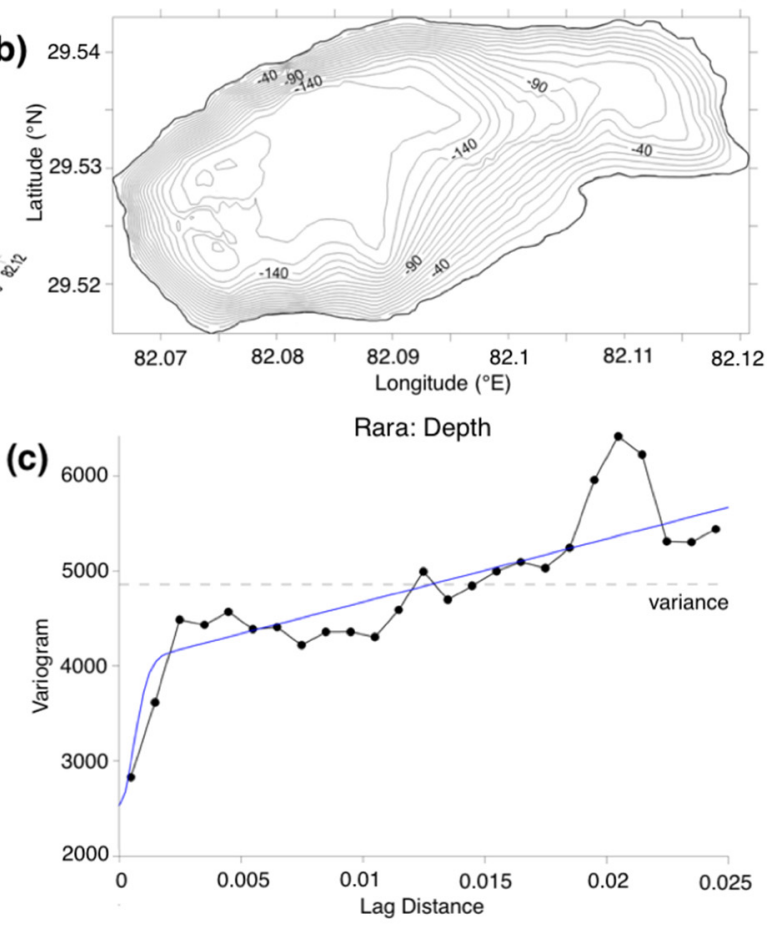

Figure 2. Variogram and bathymetry map of Rara Lake: (a) 3D visualization of the lake showing the underwater lake topography, (b) 2D contour representation of the lake surface, and (c) variogram model fitting for the surveyed depth points for the kriging interpolation. 


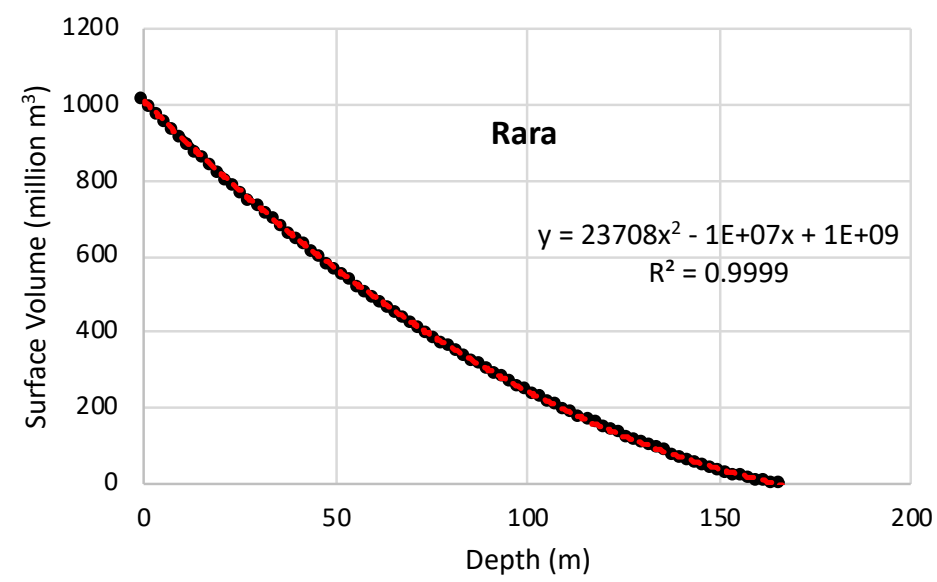

Figure 3. Relationship between water volume and depth of Rara Lake.

\subsubsection{Begnas Lake}

Figure 4 shows the bathymetric model of Begnas Lake. The Begnas Lake had a maximum depth of $12.5 \mathrm{~m}$ in the southeastern end and a mean depth of $6.6 \mathrm{~m}$. The surface area of the lake was $2.98 \pm 0.10 \mathrm{~km}^{2}$ in 2019 . The estimated water volume of the lake was $13.539 \mathrm{Mm}^{3}$. The total basin area was $49 \mathrm{~km}^{2}$. The estimated volume of the Begnas Lake $\left(13.539 \mathrm{Mm}^{3}\right)$ in this study is lower than the $17.960 \mathrm{Mm}^{3}$ reported in 1995 [15]. The primary water sources for the lake are seasonal rainfall and groundwater from the watershed.

(a)

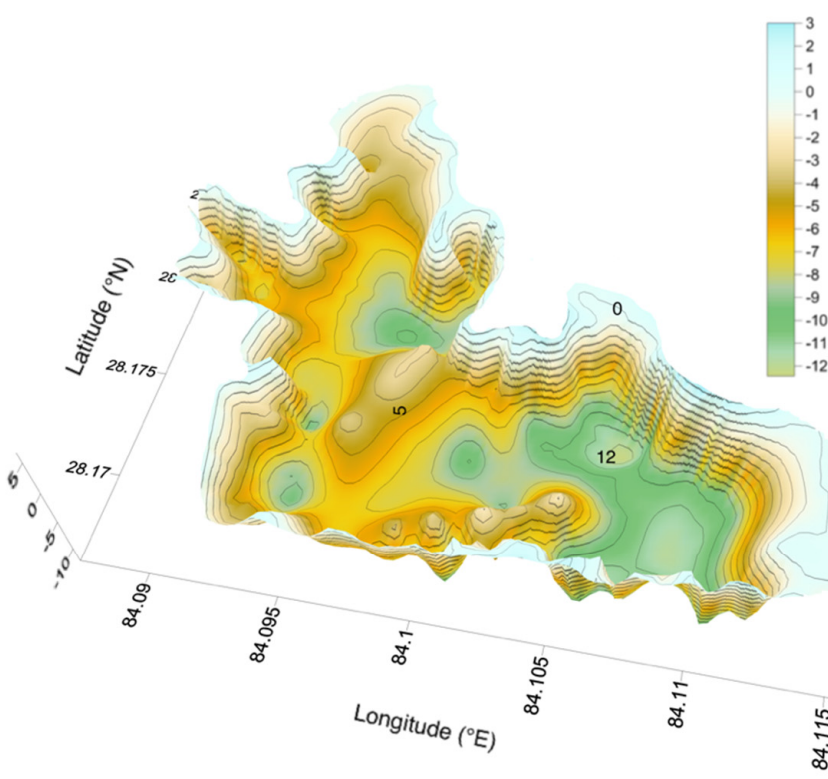

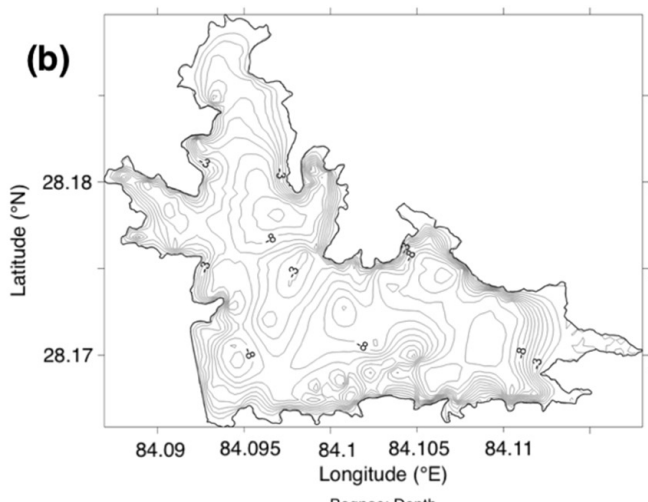

(c)

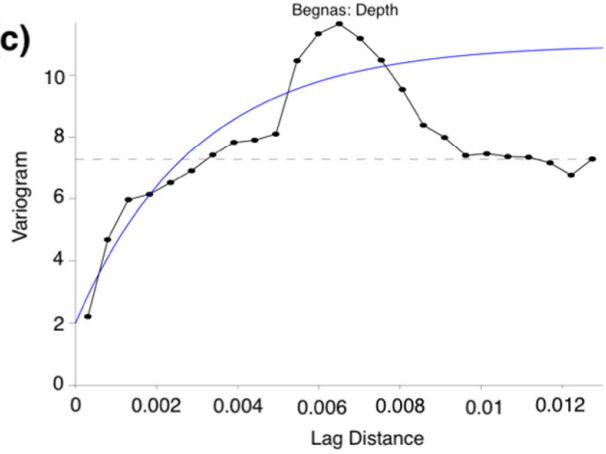

Figure 4. Variogram and bathymetry map of Begnas Lake: (a) 3D visualization of the lake showing the underwater lake topography, (b) 2D contour representation of the lake surface, and (c) variogram model fitting for the surveyed depth points for the kriging interpolation.

The bathymetry of the Begnas Lake is irregularly shaped with a flat bottom and a maximum depth of $12.5 \mathrm{~m}$. The lake gets fed from multiple inlets, which contribute to maintaining the water level. The Syangkhudi River is the main inlet stream for the Begnas lake, which is located to the northwest end of the Lake. The lake consists of hard bedrock and low soil in the benthic zone, where the shore is lined by natural forests (west and 
southern parts), whereas muddy soil is present around the northern main inlet of the lake. Forests and agricultural fields surround the shoreline of the lake. We established a second-order polynomial model to explain the relationship between the lake depth and volume (Figure 5).

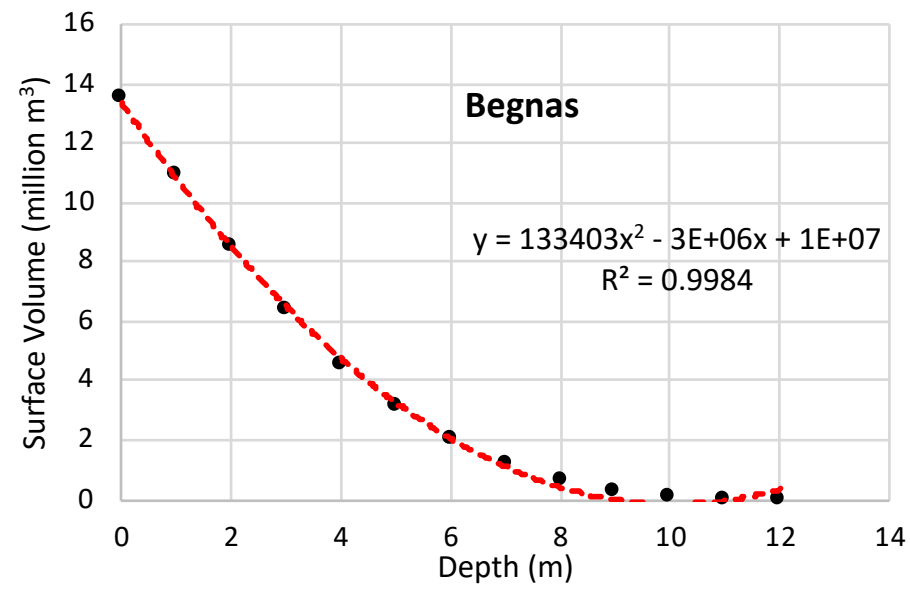

Figure 5. Relationship between water volume and depth of Begnas Lake.

\subsection{Evolution of Rara and Begnas Lakes}

We observed no significant change in the Rara Lake (Figure 6a-c), considering the uncertainty of measurement through the satellite imagery. The lake had an area of $10.39 \pm$ $0.42 \mathrm{~km}^{2}$ in $1976,10.44 \pm 0.21 \mathrm{~km}^{2}$ in 2000 , and $10.52 \pm 0.10 \mathrm{~km}^{2}$ in 2019 .
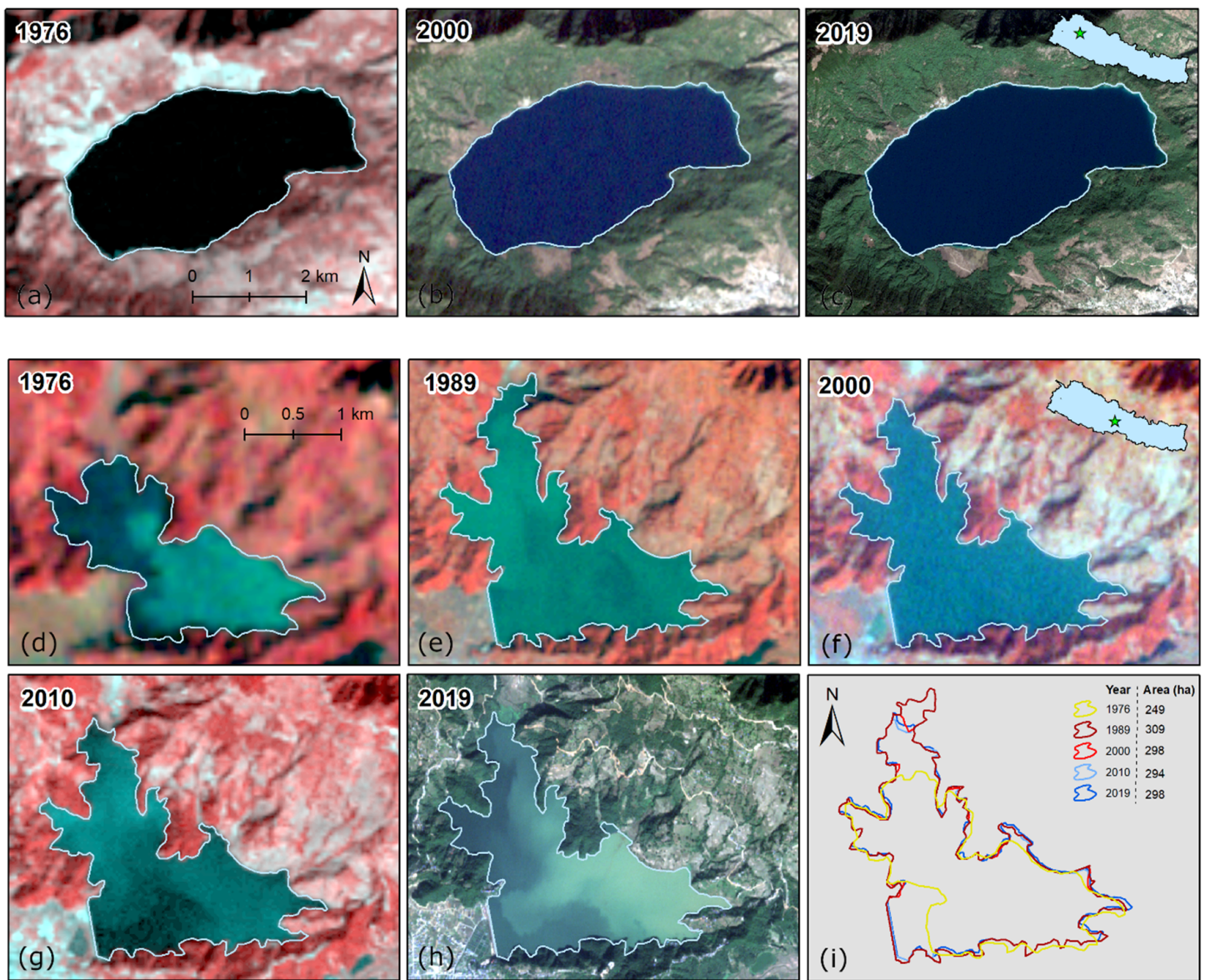

Figure 6. Evolution of Rara (a-c) and Begnas Lakes (d-i) between 1976 and 2019. 
On the other hand, the Begnas lake area was $2.49 \pm 0.26 \mathrm{~km}^{2}$ in $1976,3.10 \pm 0.20 \mathrm{~km}^{2}$ in 1989, and $2.98 \pm 0.10 \mathrm{~km}^{2}$ in 2019 . The present outlet of the lake is situated at the southwest corner of the lake. A dam was constructed at the southwest side of the lake in 1988, after which the lake water has been regulated. The primary function of the dam is water storage for irrigation and some parts of the lake for caged fisheries [45]. After establishing the dam, the surface area, volume, and depth were increased [15], as reflected by the increased surface area in the satellite imagery of 1989 (Figure 6e). Before damming the lake, Ferro and Swar [46] reported a maximum depth of $7.5 \mathrm{~m}$ with a surface area of 244 ha, which increased to 309 ha after dam construction in Begnas Lake.

After the increase in size of the lake in 1989, a continuous shrinkage of the lake was observed, especially in the northern part (Figure 6d-i and Table 3); however, the changes in the surface area of the lake were nominal as the total area change did not exceed the total error in mapping. Water level and water surface area fluctuated as a function of season and precipitation amount.

Table 3. Land-cover change of Rara and Begnas Lake watersheds from 1976 to 2019.

\begin{tabular}{|c|c|c|c|}
\hline \multirow{2}{*}{ Landcover } & \multicolumn{3}{|c|}{ Total Area $\left(\mathbf{k m}^{2}\right)$} \\
\hline & 1976 & 2000 & 2019 \\
\hline \multicolumn{4}{|l|}{ (a) Rara watershed } \\
\hline Forest & 12.51 & 13.19 & 13.60 \\
\hline Waterbody & 9.61 & 9.96 & 10.25 \\
\hline Agriculture/settlement & 2.96 & 1.74 & 0.97 \\
\hline Bare & 0.10 & 0.20 & 0.28 \\
\hline \multicolumn{4}{|l|}{ (b) Begnas watershed } \\
\hline Forest & 14.12 & 11.47 & 12.00 \\
\hline Waterbody & 2.48 & 2.99 & 2.98 \\
\hline Agriculture/settlement & 1.54 & 3.39 & 3.12 \\
\hline Bare & 0.16 & 0.43 & 0.19 \\
\hline
\end{tabular}

\subsection{Watershed Characterization (Land-Use Change and Sedimentation)}

Forest area surrounds the Rara Lake with small patches of grass/shrublands (Figure 7a-c). There were no or subtle changes in the land cover of Rara watershed from 1990 to 2019 (Table 3).
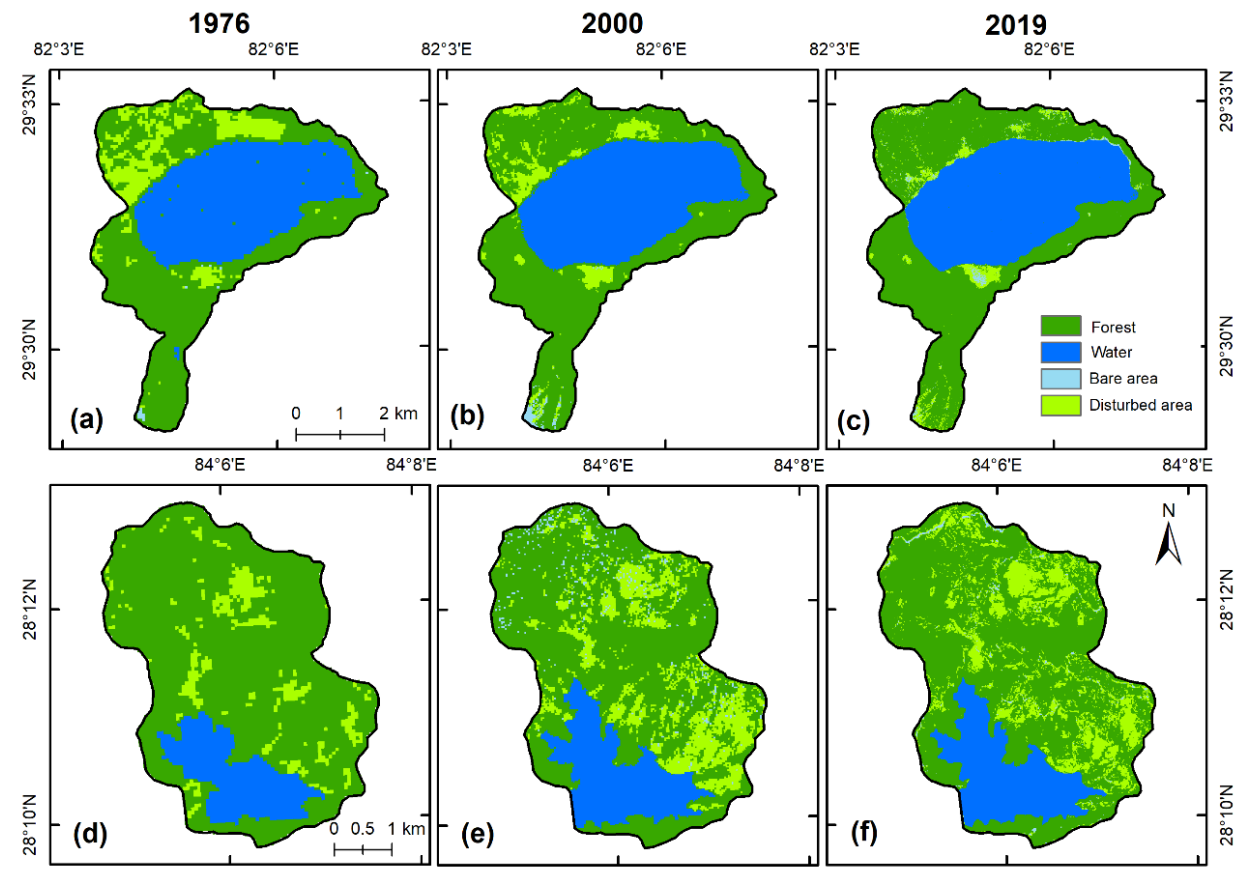

Figure 7. Land-cover change of Rara (a-c) and Begnas (d-f) watersheds between 1976 and 2019. 
Figure 8 presents the soil erosion estimate for the two lake watersheds using the methods described in [37]. The estimated mean soil erosion in the Rara Lake watershed was 1.32 ton/ha/year, ranging from 0 to 14 ton/ha/year. In contrast, the mean soil erosion in the Begnas Lake watershed was 47.63 ton/ha/year, ranging from 0 to 230 tons/ha/year, indicating a higher value than the Nepal mean (25 ton/ha/year; [37]).
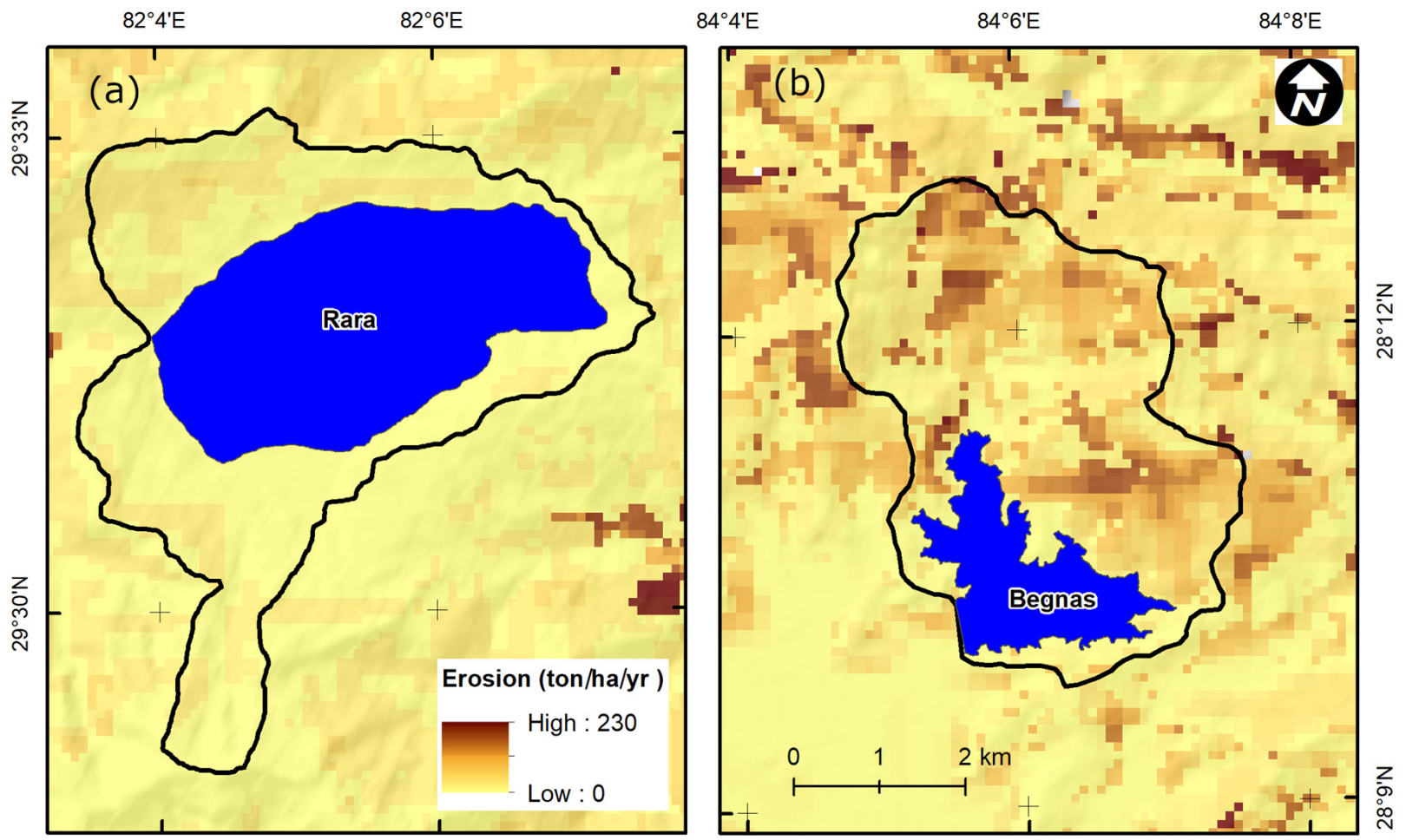

Figure 8. Soil erosion map of (a) Rara and (b) Begnas watersheds.

Yagi and others [14], according to a bathymetric survey of Rara Lake using an ultrasonic depth sounder and GPS, reported a maximum depth of $169 \mathrm{~m}$, similar to that recorded during this bathymetric survey. Nevertheless, the study did not provide other information on the area and volume. Furthermore, temporal change analysis using satellite imagery did not indicate a significant change in the lake surface area. The settlements in the Rara watershed, after the declaration of the Rara National Park, were removed. As a consequence, the human activities decreased and, simultaneously, the forest (vegetation) coverage increased. As a consequence, the sediment flux into the lake is considerably low.

Rai and others [15] found that the surface area, water volume, maximum depth, and average depth of the Begnas Lake were $3.28 \mathrm{~km}^{2}, 17.963 \mathrm{Mm}^{3}, 10 \mathrm{~m}$, and $6.6 \mathrm{~m}$, respectively. After the dam construction in the Begnas Lake [46,47], the depth and surface area of the lake increased. The main source of the lake is the Shyankhudi Stream, which flows into the lake from west to south. The growing human activities and agriculture practices in the Begnas watershed could have caused higher sedimentation and siltation, as well as eutrophication. Lama and others [48], as an example, presented evidence of the growth of the various macrophytes in the Begnas Lake. Pant and others [49] indicated, in Begnas Lake, an increased level of phosphate and the emerging problem of eutrophication. This may be due to the increased human activities in the lake watershed. Furthermore, in a nearby location, Watson and others [26] demonstrated that the degrading watershed could induce increased sediment flux into the lakes.

In the Begnas Lake watershed, agriculture-related land transformation is the dominant human force affecting water resources. Land-use change in the watershed has a direct effect on the changes in the water balance of a lake due to its linkage with evapotranspiration (ET). ET varies with the land use and land-cover types, and it changes with the transformation 
of these classes [50,51]. The highest ET occurs from water bodies, followed by the nonwetland vegetation and non-vegetated areas, respectively [52]. Lowland land-use change has a higher impact on the hydrology than highland land-use change [51].

In general, forest ecosystems have a higher ET than meadows or cultivated lands due to their higher biomass [53]. A larger forest area results in less water yield in streams since forests transpire more water in fluvial systems; however, deforestation can increase ET and decrease water yield if the deforestation results in paddy land or irrigated cropland [54]. Furthermore, increasing built-up area generally decreases ET and increases water yield. Tropical forests and farmlands have higher ET than temperate forests and farmlands. Among farmlands, paddies have the highest ET, followed by wheat and maize fields [53-55].

\subsection{Climatic Trends}

Table 4 and Figure 9 shows the mean temperature and annual precipitation trends from 1975 to 2015 according to the station data. The mean temperatures of both Rara and Begnas Lakes increased significantly $(p<0.05)$, while the annual precipitation trend in Rara showed decreasing trend (statistically significant) and that in Begnas was unclear. Precipitation directly contributes to the changes in lake water volume. Such lakes are considered good indicators of the precipitation change $[1,21,56]$ since they have contributions from rainfall and groundwater. Increased temperature contributes to the increased conversion of water into vapor through ET.

Table 4. Temperature and precipitation trends (1975-2015) in the Begnas and Rara Lakes.

\begin{tabular}{cccc}
\hline Site & Station & Mean Temperature $\left({ }^{\circ} \mathbf{C} / \mathbf{y r}\right)$ & Annual Rainfall $(\mathbf{m m} / \mathbf{y r})$ \\
\hline Rara & 303 & $0.035^{*}$ & $-3.2^{*}$ \\
& 310 & $0.042^{*}$ & $-3.5^{*}$ \\
\hline \multirow{2}{*}{ Begnas } & 804 & $0.035^{*}$ & -4.7 \\
& 814 & $0.030^{*}$ & 20.1 \\
\hline
\end{tabular}

* statistically significant at $\alpha=0.05$.

High mountain areas are more rapidly warming compared to the southern lowlands of Nepal [57]. In areas above $1000 \mathrm{~m}$ elevation in Nepal, the maximum temperature has increased by $0.072{ }^{\circ} \mathrm{C}$ per year, while, in the areas below $1000 \mathrm{~m}$, the maximum temperature has only increased by $0.028^{\circ} \mathrm{C}$ per year in the last four decades (1976-2015). This rising temperature causes fluctuations in precipitation in high mountains, which is an essential source of water for the lake recharge. Potential ET decreases with increasing elevation in Nepal [58]; however, the evaporation/precipitation ratio at higher elevation is low, and the lake variation can be attributed to precipitation [59]. Salerno et al. [21] confirmed that precipitation trends could be detected as a function of the surface area changes of Himalayan lakes. Thus, lakes are a good indicator of precipitation and temperature change. Changes in the distribution and number of lakes have implications for hydrology and the ecosystem [12]. 

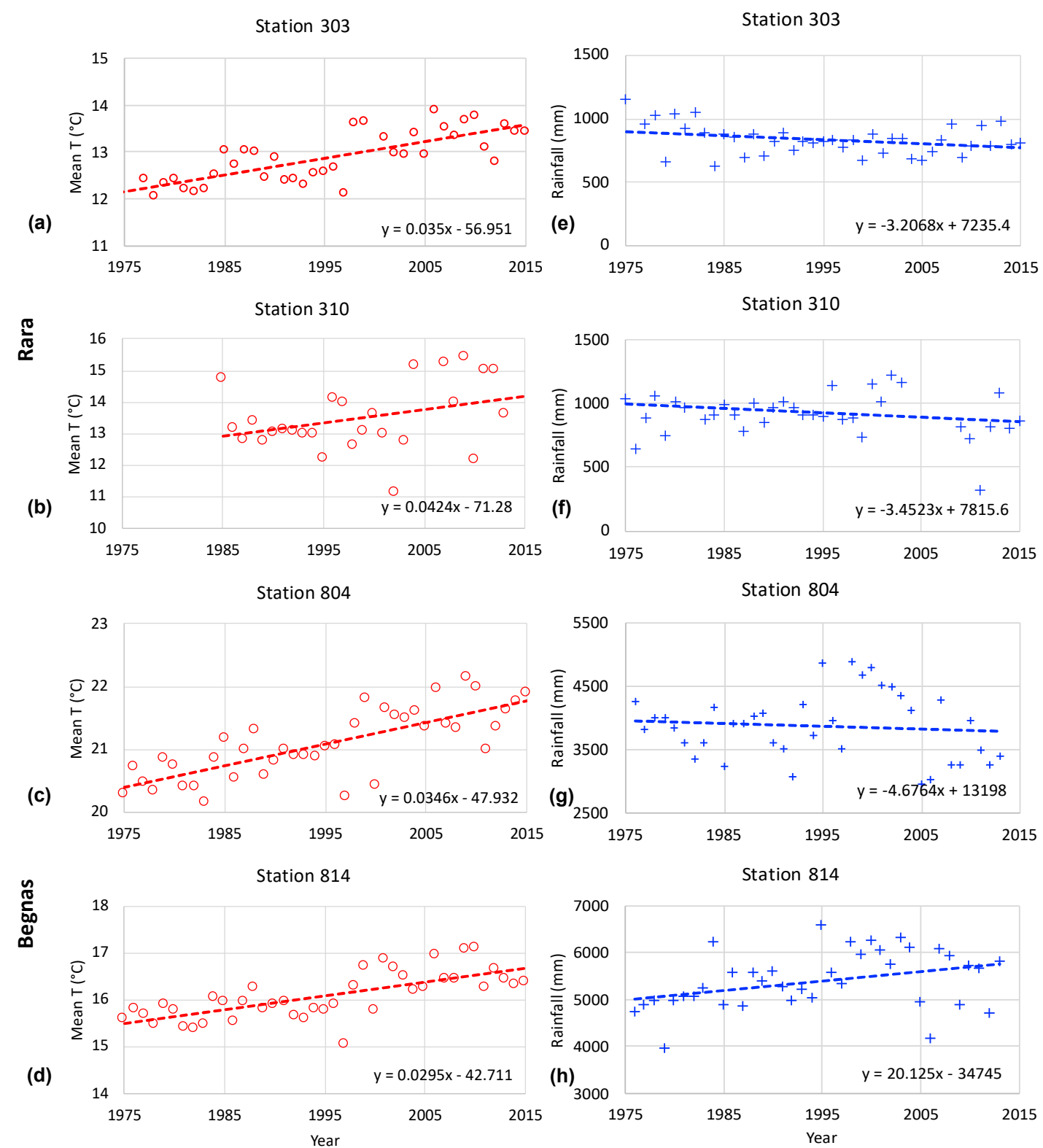

Figure 9. Annual mean temperature (a-d) and total precipitation (e-h) trends in the Rara (a,b,e,f) and Begnas (c,d,g,h) Lakes, according to the ground station data.

\section{Conclusions}

This study presented the bathymetric modeling of two permanent lakes (Begnas and Rara), located in two different geographic settings of Nepal. The temporal lake variations were analyzed, and the impacts of human activities and climate change on the lakes were evaluated. A model was established for representing the water volume and depth of the lakes, aimed at establishing reference sites for exploring the scientific evidence of climate change impacts on hydrological systems. Quantitative knowledge on the temporal changes of lake surfaces was obtained, and the potential fate of the lakes was explained in term of their watershed dynamics by analyzing the temporal changes in land cover and soil erosion, as well as the climatic trends around the two lakes.

Lake evolution and its dynamics are a highly visible and easily measurable signal of the impact of human activities and climate change in mountain ecosystems. The lake depth and volume could be the best represented by second-order polynomial models. The Rara Lake had a maximum depth of $169 \mathrm{~m}$ with an area of $10.52 \mathrm{~km}^{2}$ and a volume of $1013.305 \mathrm{Mm}^{3}$, whereas the Begnas Lake had a maximum depth of $12.5 \mathrm{~m}$ with an area of 
$2.98 \pm 0.10 \mathrm{~km}^{2}$ and a surface volume of $13.539 \mathrm{Mm}^{3}$. Both lake locations are experiencing changes in temperature and precipitation. The area and volume of Rara Lake and its watershed are relatively stable even though some land-cover change has been observed in recent years. Begnas Lake and its watershed have experienced a significant change in the last few decades. We conclude that human activities played a dominant role in the variation of Begnas Lake. The dynamics of the lake watershed and human activities are the prime sources of the changes in lake area.

Author Contributions: Conceptualization, S.T.; methodology, S.T. and F.L.; investigation, S.T., F.L., and N.P.G.; formal analysis, S.T., F.L., and N.K.; visualization, S.T.; writing (original draft preparation), S.T.; writing (review and editing), N.K., N.P.G., R.M., and F.S.; supervision, R.M. and F.S. All authors read and agreed to the published version of the manuscript.

Funding: This research received no external funding.

Institutional Review Board Statement: Not applicable.

Informed Consent Statement: Not applicable.

Data Availability Statement: The datasets generated and/or analyzed during the current study are available from the corresponding author on reasonable request.

Acknowledgments: This work was supported by the CREEW's Young Research Fellowship to S. Thakuri. N. Khadka acknowledges the Chinese Academy of Sciences-The World Academy of Science (CAS-TWAS) President's Fellowship for doctorate study.

Conflicts of Interest: The authors declare no conflict of interest.

\section{References}

1. Lei, Y.; Yang, K.; Wang, B.; Sheng, Y.; Bird, B.W.; Zhang, G.; Tian, L. Response of inland lake dynamics over the Tibetan Plateau to climate change. Clim. Chang. 2014, 125, 281-290. [CrossRef]

2. Shijin, W.; Tao, Z. Spatial change detection of glacial lakes in the Koshi River Basin, the Central Himalayas. Environ. Earth Sci. 2014, 72, 4381-4391. [CrossRef]

3. Sharma, C.M.; Sharma, S.; Gurung, S.; Bajracharya, R.M.; Jüttner, I. Study on Morphometry and Limnology of Gokyo Wetland with Climate Change Perspective; Report WWF; World Wildlife Fund: Nepal, Kathmandu, 2009.

4. Khadka, N.; Zhang, G.; Thakuri, S. Glacial lakes in the Nepal Himalaya: Inventory and decadal dynamics (1977-2017). Remote Sens. 2018, 10, 1913. [CrossRef]

5. Thakuri, S.; Salerno, F.; Smiraglia, C.; Bolch, T.; D'Agata, C.; Viviano, G.; Tartari, G. Tracing glacier changes since the 1960s on the south slope of Mt. Everest (central Southern Himalaya) using optical satellite imagery. Cryosphere 2014, 8, 1297-1315. [CrossRef]

6. Khadka, N.; Zhang, G.; Chen, W. The state of six dangerous glacial lakes in the Nepalese Himalaya. Terr. Atmos. Ocean. Sci. 2019, 30, 63-72. [CrossRef]

7. Somos-Valenzuela, M.A.; McKinney, D.C.; Rounce, D.R.; Byers, A.C. Changes in Imja Tsho in the Mount Everest region of Nepal. Cryosphere 2014, 8, 1661-1671. [CrossRef]

8. Sakai, A.; Yamada, T.; Fujita, K. Volume change of Imja glacial lake in the Nepal Himalayas. In Proceedings of the International Symposium on Disaster Mitigation and Basin Wide Water Management, Niigata, Japan, 7-10 December 2003; pp. 556-561.

9. Thapa, S.; Wang, L.; Koirala, A.; Shrestha, S.; Bhattarai, S.; Aye, W.N. Valuation of Ecosystem Services from an Important Wetland of Nepal: A Study from Begnas Watershed System. Wetlands 2020, 40, 1071-1083. [CrossRef]

10. Paudyal, K.; Baral, H.; Keenan, R.J. Assessing social values of ecosystem services in the Phewa Lake Watershed, Nepal. For. Policy Econ. 2018, 90, 67-81. [CrossRef]

11. Bhuju, U.R.; Khadka, M.; Neupane, P.K.; Adhikari, R. Lakes of Nepal: 5358-A Map-Based Inventory; National Lakes Conservation Development Committee: Kathmandu, Nepal, 2009.

12. Shrestha, B.; Ye, Q.; Khadka, N. Assessment of Ecosystem Services Value Based on Land Use and Land Cover Changes in the Transboundary Karnali River Basin, Central Himalayas. Sustainability 2019, 11, 3183. [CrossRef]

13. Sewwandi, B.G.N.; Wickramaratne, K.N.K.R.; Jayasinghe, D.M.R.R.; Sangeetha, M.; Galagedara, L.W.; Dayawansa, N.D.K. Water allocation of Begnas lake in Nepal among different sectors: A comparison with Sri Lankan dry zone small irrigation systems. In Proceedings of the Water Professional's Day, Water Resources Research in Sri Lanka, Peradeniya, Sri Lanka, 1 October 2009.

14. Yagi, H.; Maekoku, H.; Okamura, A.; Matsuoka, H.; Teramura, H.; Adhikari, D.; Dangol, V. Rara Lake, its bathymetric feature and origin, Jumla District, western Nepal Himalayas. J. Nepal Geol. Soc. 2009, 155, 59-62.

15. Rai, A.K.; Shrestha, B.C.; Joshi, P.L.; Gurung, T.B.; Nakanishi, M. Bathymetric maps of Lakes Phewa, Begnas and Rupa in Pokhara Valley, Nepal. Mem. Fac. Sci. Kyoto Univ. Ser. Biol. 1995, 16, 49-54. 
16. Okino, T.; Satoh, Y. Morphology, physics, chemistry and biology of Lake Rara in West Nepal. Hydrobiologia 1986, 140, 125-133. [CrossRef]

17. Gurung, A.; Adhikari, S.; Chauhan, R.; Thakuri, S.; Nakarmi, S.; Ghale, S.; Dongol, B.S.; Rijal, D. Water crises in a water-rich country: Case studies from rural watersheds of Nepal's mid-hills. Water Policy 2019, 21, 826-847. [CrossRef]

18. Rafiq, L.; Blaschke, T. Disaster risk and vulnerability in Pakistan at a district level. Geomat. Nat. Hazards Risk 2012, 3, 324-341. [CrossRef]

19. Gupta, S.K.; Deshpande, R.D. Water for India in 2050: First-order assessment of available options. Curr. Sci. 2004, 86, 1216-1224.

20. Zhang, Z.; Chang, J.; Xu, C.Y.; Zhou, Y.; Wu, Y.; Chen, X.; Jiang, S.; Duan, Z. The response of lake area and vegetation cover variations to climate change over the Qinghai-Tibetan Plateau during the past 30 years. Sci. Total Environ. 2018, 635, 443-451. [CrossRef] [PubMed]

21. Salerno, F.; Thakuri, S.; Guyennon, N.; Viviano, G.; Tartari, G. Glacier melting and precipitation trends detected by surface area changes in Himalayan ponds. Cryosphere 2016, 10, 1433-1448. [CrossRef]

22. Nelson, G.C.; Rosegrant, M.W.; Koo, J.; Robertson, R.; Sulser, T.; Zhu, T.; Ringler, C.; Msangi, S.; Palazzo, A.; Batka, M.; et al. Climate Change: Impact on Agriculture and Costs of Adaptation; Food Policy Report; International Food Policy Research Institute: Washington, DC, USA, 2009.

23. Kafle, G.; Savillo, I.T. Present status of Ramsar sites in Nepal. Int. J. Biodivers. Conserv. 2009, 1, 146-150.

24. Bhuju, U.R.; Shakya, P.R.; Basnet, T.B.; Shrestha, S. Nepal Biodiversity Resource Book: Protected Areas, Ramsar Sites, and World Heritage Sites; International Centre for Integrated Mountain Development (ICIMOD): Kathmandu, Nepal, 2007.

25. Acharya, T.D.; Yang, I.T.; Subedi, A.; Lee, D.H. Change detection of lakes in Pokhara, Nepal using Landsat data. Proceedings 2017, 1, 17. [CrossRef]

26. Watson, C.S.; Kargel, J.S.; Regmi, D.; Rupper, S.; Maurer, J.M.; Karki, A. Shrinkage of Nepal's second largest Lake (Phewa tal) due to watershed degradation and increased sediment influx. Remote Sens. 2019, 11, 444. [CrossRef]

27. Ferro, W. Some limnological and biological data from Rara, a deep Himalayan Lake in Nepal. J. Nepal Centre 1979, 2/3, $241-261$.

28. Rai, A.K. Limnological characteristics of subtropical Lakes Phewa, Begnas, and Rupa in Pokhara Valley, Nepal. Limnology 2000, 1, 33-46. [CrossRef]

29. Paudel, N.; Adhikari, S.; Paudel, G. Ramsar lakes in the foothills of Himalaya, Pokhara-Lekhnath, Nepal: An overview. Janapriya J. Interdiscip. Stud. 2017, 6, 134-147. [CrossRef]

30. Nakanishi, M.; Watanave, M.M.; Terashima, A.; Sako, Y.; Konda, T.; Shrestha, K.; Bhandary, H.; Ishida, Y. Studies on some limnological variables in subtropical lakes of the Pokhara Valley, Nepal. Jpn. J. Limnol. Rikusuigaku Zasshi 1988, 49, 71-86. [CrossRef]

31. Davis, M.F.; Gurung, T.B.; Shrestha, B.; Jones, S.B.; Wylie, G.D.; Perkins, B.D.; Jones, J.R. Use of a subsurface plankton layer to benefit a cage-culture fishery in Lake Phewa, Nepal. Int. Ver. Theor. Angew. Limnol. Verh. 1998, 26, 2220-2227. [CrossRef]

32. Khadka, U.R.; Ramanathan, A.L. Major ion composition and seasonal variation in the Lesser Himalayan lake: Case of Begnas Lake of the Pokhara Valley, Nepal. Arab. J. Geosci. 2013, 6, 4191-4206. [CrossRef]

33. Lohman, K.; Jones, J.R.; Knowlton, M.F.; Swar, D.B.; Pamperl, M.A.; Brazos, B.J. Pre-and postmonsoon limnological characteristics of lakes in the Pokhara and Kathmandu Valleys, Nepal. Int. Ver. Theor. Angew. Limnol. Verh. 1988, 23, 558-565. [CrossRef]

34. Jones, J.R.; Knowlton, M.; Swar, D.B. Limnological reconnaissance of waterbodies in central and southern Nepal. Hydrobiologia 1989, 184, 171-189. [CrossRef]

35. Ferro, W. Limnology of the Pokhara Valley Lakes (Himalayan Region, Nepal) and Its Implication for Fisery and Fish Culture; Report Integrated Fishery and Fish Culture Development Project; FAO: Rome, Italy, 1978.

36. Popielarczyk, D.; Templin, T.; Łopata, M. Using the geodetic and hydroacoustic measurements to investigate the bathymetric and morphometric parameters of Lake Hancza (Poland). Open Geosci. 2015, 7, 854-869. [CrossRef]

37. Koirala, P.; Thakuri, S.; Joshi, S.; Chauhan, R. Estimation of soil erosion in Nepal using a RUSLE modeling and geospatial tool. Geosciences 2019, 9, 147. [CrossRef]

38. Nie, Y.; Sheng, Y.; Liu, Q.; Liu, L.; Liu, S.; Zhang, Y.; Song, C. A regional-scale assessment of Himalayan glacial lake changes using satellite observations from 1990 to 2015. Remote Sens. Environ. 2017, 189, 1-13. [CrossRef]

39. Thakuri, S.; Salerno, F.; Bolch, T.; Guyennon, N.; Tartari, G. Factors controlling the accelerated expansion of Imja Lake, Mount Everest region, Nepal. Ann. Glaciol. 2016, 57, 245-257. [CrossRef]

40. Mallick, J.; Hasan, M.A.; Alashker, Y.; Ahmed, M. Bathymetric and geochemical analysis of lake al-saad, Abha, kingdom of Saudi Arabia using geoinformatics technology. J. Geogr. Inf. Syst. 2014, 6, 440. [CrossRef]

41. Šiljeg, A.; Lozić, S.; Šiljeg, S. A comparison of interpolation methods on the basis of data obtained from a bathymetric survey of Lake Vrana, Croatia. Hydrol. Earth Syst. Sci. 2015, 19, 3653-3666. [CrossRef]

42. Kunkel, K.E.; Easterling, D.R.; Redmond, K.; Hubbard, K. Temporal variations of extreme precipitation events in the United States: 1895-2000. Geophys. Res. Lett. 2003, 30, 1900. [CrossRef]

43. Ngongondo, C.; Xu, C.Y.; Gottschalk, L.; Alemaw, B. Evaluation of spatial and temporal characteristics of rainfall in Malawi: A case of data scarce region. Theor. Appl. Climatol. 2011, 106, 79-93. [CrossRef]

44. Hameed, T.; Mariño, M.A.; DeVries, J.J.; Tracy, J.C. Method for trend detection in climatological variables. J. Hydrol. Eng. 1997, 2, 154-160. [CrossRef] 
45. Swar, D.B.; Gurung, T.B. Introduction and cage culture of exotic carps and their impact on fish harvested in Lake Begnas, Nepal. Hydrobiologia 1988, 166, 277-283. [CrossRef]

46. Ferro, W.; Swar, D.B. Bathymetric maps from three lakes in the Pokhara Valley (Nepal). J. Inst. Sci. TU 1978, 1, 177-188.

47. Acharya, S.; Can-Ge, L.I.; JI, K.; Sun, Z.; Wang, M.; Hou, J. Lacustrine Record of 1954 Flood Event on Begnas and Rupa Lake, Central Nepal. Acta Geol. Sinica Engl. Ed. 2020, 94, 717-724. [CrossRef]

48. Lama, F.; Thakuri, S.; Ghimire, N.P.; Malla, R. Ecotone vegetation and water quality of Rara and Begnas Lakes, Nepal. Himalayan Biodivers. 2018, 6, 27-37. [CrossRef]

49. Pant, R.; Pal, K.; Adhikari, N.; Adhikari, S.; Mishra, A. Water Quality Assessment of Begnas and Rupa Lakes, Lesser Himalaya Pokhara, Nepal. J. Inst. Eng. 2019, 15, 113-122. [CrossRef]

50. Odongo, V.O.; van Oel, P.R.; van der Tol, C.; Su, Z. Impact of land use and land cover transitions and climate on evapotranspiration in the Lake Naivasha Basin, Kenya. Sci. Total Environ. 2019, 682, 19-30. [CrossRef]

51. Dunn, S.M.; Mackay, R. Spatial variation in evapotranspiration and the influence of land use on catchment hydrology. J. Hydrol. 1995, 171, 49-73. [CrossRef]

52. Liu, M.; Hu, D. Response of wetland evapotranspiration to land use/cover change and climate change in Liaohe River Delta, China. Water 2019, 11, 955. [CrossRef]

53. Guo, R.P.; Mo, X.G. Differences of evapotranspiration on forest, grassland and farmland. J. Appl. Ecol. 2007, 18, $1751-1757$.

54. Liu, M.; Tian, H.; Chen, G.; Ren, W.; Zhang, C.; Liu, J. Effects of land-use and land-cover change on evapotranspiration and water yield in China during 1900-2000. JAWRA J. Am. Water Resour. Assoc. 2008, 44, 1193-1207. [CrossRef]

55. Verstraeten, W.W.; Veroustraete, F.; Feyen, J. Estimating evapotranspiration of European forests from NOAA-imagery at satellite overpass time: Towards an operational processing chain for integrated optical and thermal sensor data products. Remote Sens. Environ. 2005, 96, 256-276. [CrossRef]

56. Adrian, R.; O’Reilly, C.M.; Zagarese, H.; Baines, S.B.; Hessen, D.O.; Keller, W.; Livingstone, D.M.; Sommaruga, R.; Straile, D.; Van Donk, E.; et al. Lakes as sentinels of climate change. Limnol. Oceanogr. 2009, 54, 2283-2297. [CrossRef]

57. Thakuri, S.; Dahal, S.; Shrestha, D.; Guyennon, N.; Romano, E.; Colombo, N.; Salerno, F. Elevation-dependent warming of maximum air temperature in Nepal during 1976-2015. Atmos. Res. 2019, 228, 261-269. [CrossRef]

58. Lambert, L.; Chitrakar, B.D. Variation of potential evapotranspiration with elevation in Nepal. Mt. Res. Dev. 1989, 9, 145-152. [CrossRef]

59. Salerno, F.; Thakuri, S.; D’Agata, C.; Smiraglia, C.; Manfredi, E.C.; Viviano, G.; Tartari, G. Glacial lake distribution in the Mount Everest region: Uncertainty of measurement and conditions of formation. Glob. Planet. Change 2012, 92, 30-39. [CrossRef] 